\title{
Early (pre-8 Ma) fault activity and temporal strain accumulation in the central Indian Ocean
}

\author{
K.S. Krishna' ${ }^{1}$, J.M. Bull2, R.A. Scrutton ${ }^{3}$ \\ ${ }^{1}$ National Institute of Oceanography, Council of Scientific and Industrial Research, Dona Paula, Goa 403004, India \\ ${ }^{2}$ School of Ocean and Earth Science, National Oceanography Centre Southampton, University of Southampton, \\ Southampton SO14 3ZH, UK \\ ${ }^{3}$ School of Geosciences, University of Edinburgh, Edinburgh EH9 3JW, UK
}

\begin{abstract}
The diffuse deformation zone in the central Indian Ocean is the classical example of distributed deformation of the oceanic lithosphere, where shortening between the Indian and Capricorn plates is manifest as reverse faulting (5-10-km-spaced faults) and long-wavelength $(100-300 \mathrm{~km})$ folding. The onset of this deformation is commonly regarded as a key far-field indicator for the start of major uplift of the Himalayas and Tibet, some $4000 \mathrm{~km}$ further to the north, due to increased deviatoric stresses within the wider India-Asia area. There has been disagreement concerning the likely timing for the onset of deformation between plate-motion inversions and seismic reflection-based studies. In the present study, fault displacement data from seismic-reflection profiles within the central Indian Ocean demonstrate that compressional activity started much earlier than previously thought, at around 15.4-13.9 Ma. From reconstructions of fault activity histories, we show that $12 \%$ of the total reverse fault population had been activated, and $14 \%$ of the total strain accumulated, prior to a sharp increase in the deformation rate at 8.0-7.5 Ma. There is no evidence for any regional unconformity before 8.0-7.5 Ma; early shortening was accommodated by activity on single isolated fault blocks. Total strain estimates derived are more variable and complex than those predicted from plate inversion, and they do not show simple west to east increase.
\end{abstract}

\section{INTRODUCTION}

Lithospheric deformation within the central Indian Ocean is recorded by the Bengal Fan sediments, the world's largest submarine fan, the thickness of which decreases uniformly to $7^{\circ} 40^{\prime} \mathrm{S}$, where it abuts exposed basement topography (Krishna et al., 2001). On the basis of seismic-reflection character (Curray et al., 1982), the sedimentary section of the Bay of Bengal has been divided into three units separated by two major unconformities (Paleocene and Miocene). While the lower sedimentary unit consists of pelagic sediment and terrigenous material derived from India before collision, the upper two sedimentary units include the Bengal Fan sediments. Around Ocean Drilling Program (ODP) Leg 116 sites (Fig. 1), the sedimentary section represents fan sedimentation over the last 25 m.y., with at least a 30 m.y. apparent hiatus between the fan and precollision sediments (Curray et al., 2002).

Seismic-reflection studies have correlated a widely observed structural unconformity within the central Indian Ocean to ODP Leg 116 sites (Fig. 1) and indicated that lithospheric deformation began at ca. 8.0-7.5 Ma (Cochran, 1990; Bull and Scrutton, 1992; Krishna et al., 1998). Subsequently, seismic stratigraphic analysis of the Bengal Fan sediments (Krishna et al., 2001) has shown that the lithosphere in the central Indian Ocean was folded at discrete times, with major events occurring in the Miocene (8.0-7.5 Ma), Pliocene (5.0-4.0 Ma), and Pleistocene (0.8 Ma).
In contrast to seismic stratigraphic and deep-sea drilling constraints on timing of deformation, plate reconstructions have indicated that motion between the Indian and Capricorn plates started before $8.0 \mathrm{Ma}$ (Gordon et al., 1998; DeMets et al., 2005), that is, deeper than the earliest deformation-related regional unconformity. Recently, a detailed analysis of the plate motion among the Indian, Capricorn, and Somalian plates (DeMets et al., 2005) predicted a small amount of north-south extension in the central Indian Ocean between 20 and $8 \mathrm{Ma}$, with onset of contractional deformation at $8 \mathrm{Ma}$, continuing to present. The early motion occurred at a relatively slow rate of $0.11^{\circ} \pm 0.01^{\circ} \mathrm{m} . \mathrm{y} .^{-1}$ (near $5^{\circ} \mathrm{N}, 85^{\circ} \mathrm{E}$ ), and increased to $0.28^{\circ} \pm 0.01^{\circ}$ m.y. ${ }^{-1}$ after $8 \mathrm{Ma}$ about a pole located near $4^{\circ} \mathrm{S}, 75^{\circ} \mathrm{E}$. Platemotion inversion between the Capricorn and Indian plates suggests a steady convergence rather than pulsed activity since $8.0 \mathrm{Ma}$, in disagreement with seismic stratigraphic studies (Krishna et al., 2001). In recent work, Delescluse et al. (2008) also found evidence from seismic-reflection profiles that deformation started before $8.0 \mathrm{Ma}$.

In this study, reverse-fault-generated vertical offsets were measured on each of the three unconformities (8.0-7.5, 5.0-4.0, and 0.8 Ma), as well as a continuous reflector above basement. These data were backstripped to determine how vertical displacement (throw) has accumulated with time. The study addresses the timing of initiation of compressional activity within the central Indian Ocean. In addition, we derive strain budgets along different longitudes to understand its accumulation with time.

\section{REVERSE FAULTS AND ONSET OF COMPRESSIONAL ACTIVITY IN THE CENTRAL INDIAN OCEAN}

Three regional, high-resolution seismic profiles (along $81.4^{\circ}, 83.7^{\circ}$, and $87^{\circ} \mathrm{E}$ ) of the Bengal Fan sediments were analyzed for the measurement of reverse-fault-generated vertical offsets at three structural unconformities (8.0-7.5, 5.0-4.0, and $0.8 \mathrm{Ma}$ ), as well as a continuous reflector above basement. In addition, we measured vertical offset at all reflectors older than $8.0 \mathrm{Ma}$ that could be confidently interpreted across fault offsets. The measurement of displacement was maximized by ensuring that measurements were taken far enough from the fault plane so that local drag effects would not be present. The vertical displacement (throw) data measured at 293 faults were then backstripped, and the stratigraphic position of the horizons that had experienced greatest offset was determined (whether the Miocene unconformity or older); those reflectors were interpreted as being representative of the age when compressional activity began.

Three short seismic-reflection profiles (Fig. 2) from different parts of the deformation zone illustrate the range of strain accumulation histories. In Figure 2A, fault F1 has greater displacement by $90 \mathrm{~ms}$ two-way time (TWT) (i.e., $\sim 130 \mathrm{~m}$ ) at horizons I and II than the Miocene unconformity at 8.0-7.5 Ma, which indicates that this fault was active well before $8.0 \mathrm{Ma}$ (43\% of strain was accumulated prior to $8 \mathrm{Ma}$ ). We used the depth-dependent velocity law determined at ODP Leg 116 sites (Bull and Scrutton, 1990b) to depth convert our measurements (Fig. 2), and hence we are confident that this observation of early compressional movement is real.

The full complexity of the fault activity history seen is demonstrated by fault F2 (Fig. 2B). Horizons III and IV have the greatest displacement, and we interpret this as representing the age at which compressional activity started. Deeper within the section, the displacement recorded by horizons V-VII progressively decreases, indicating early normal fault activity. Higher up in the section (Fig. 2B), the Miocene unconformity shows slightly lower 
displacement than horizon III and IV, and we conclude that compressional activity had already begun. As expected, the Pliocene and Pleistocene unconformities have had less time to accumulate displacement.

Figure 2C shows faults F3 and F4, which reveal that 25 and $45 \mathrm{~ms}$ TWT of displacement, respectively, occurred before the Miocene unconformity and after horizon VIII. For horizon IX, we find that 10 and $35 \mathrm{~ms}$ TWT of displacement occurred on faults F3 and F4 between the age of its formation and the Miocene unconformity. Fault F4 has a complex fault activity history, with some early normal movement. For faults F3 and F4, we find that the majority of the strain was accumulated before $8.0 \mathrm{Ma}$.

The three examples shown in Figure 2 are representative of the 293 faults for which we determined fault activity histories. The complete fault population analysis is summarized in Table DR1 in the GSA Data Repository. ${ }^{1}$ Overall, $12 \%$ of faults were found to have been active before 8.0 Ma, and these faults accumulated $14 \%$ of the total strain. While the evidence for activity earlier than 8.0 Ma is clear, we cannot accurately constrain the precise age of deformation onset. However, if we use biostratigraphic age data for ODP Site 718 (Gartner, 1990), and the depthdependent velocity profile of Bull and Scrutton (1990b), to derive the sedimentation rate for the period from 8 to $16 \mathrm{Ma}$, and consider this rate to be representative for the sediment interval between the Miocene unconformity and the onset of deformation, we find that the mean age for the onset of deformation is $14.65 \pm 0.75 \mathrm{Ma}$ ( $95 \%$ confidence interval), giving a likely range of 15.4-13.9 Ma.

In addition to the 15.4-13.9 Ma compressional activity, we find evidence for a few faults with very early normal movement (i.e., at the time of deposition of horizons V-VII in Fig. 2B), which were subsequently reactivated as reverse faults. Evidence for this normal fault activity is concentrated in the lowest sedimentary packages, and it is difficult to constrain the magnitude of this extension in any regional sense because diminishing vertical resolution with depth allows its identification only on the clearest seismic sections. However, our observation of early normal faulting is consistent with DeMets et al. (2005), who speculated that some of the faults that have accommodated shortening during the last 8 m.y. may have accommodated extension before $8 \mathrm{Ma}$. Age control on the deeper sediments is limited, but assuming sedimentation rates derived from ODP Site 718 are applicable throughout

GSA Data Repository item 2009061, summary of fault population and strain characterization within the central Indian Ocean derived from six north-south seismic reflection profiles, is available online at www. geosociety.org/pubs/ft2009.htm, or on request from editing@geosociety.org or Documents Secretary, GSA, P.O. Box 9140, Boulder, CO 80301, USA.
Figure 1. Locations of seismic-reflection profiles within central Indian Ocean from which fault throw data have been derived. ANS and NER indicate Afanasy Nikitin seamount and Ninetyeast Ridge, respectively. Shading (yellow) shows position of diffuse plate boundary separating Capricorn (CAP), Indian (IND), and Australian (AUS) plates (Royer and Gordon, 1997). Approximate spatial extents of long-wavelength folding at three different phases (8.0-7.5, red; 5.0-4.0, light blue; $0.8 \mathrm{Ma}$, green; Krishna et al., 2001) are superimposed on this area. Inset map shows regional plate geometry (Royer and Gordon, 1997). Star shows approximate location of IndiaCapricorn pole of rotation (Gordon et al., 1998), which predicts compression in central Indian Ocean and extension around Chagos Bank (Henstock and Minshull, 2004). DSDP-Deep Sea Drilling Project.

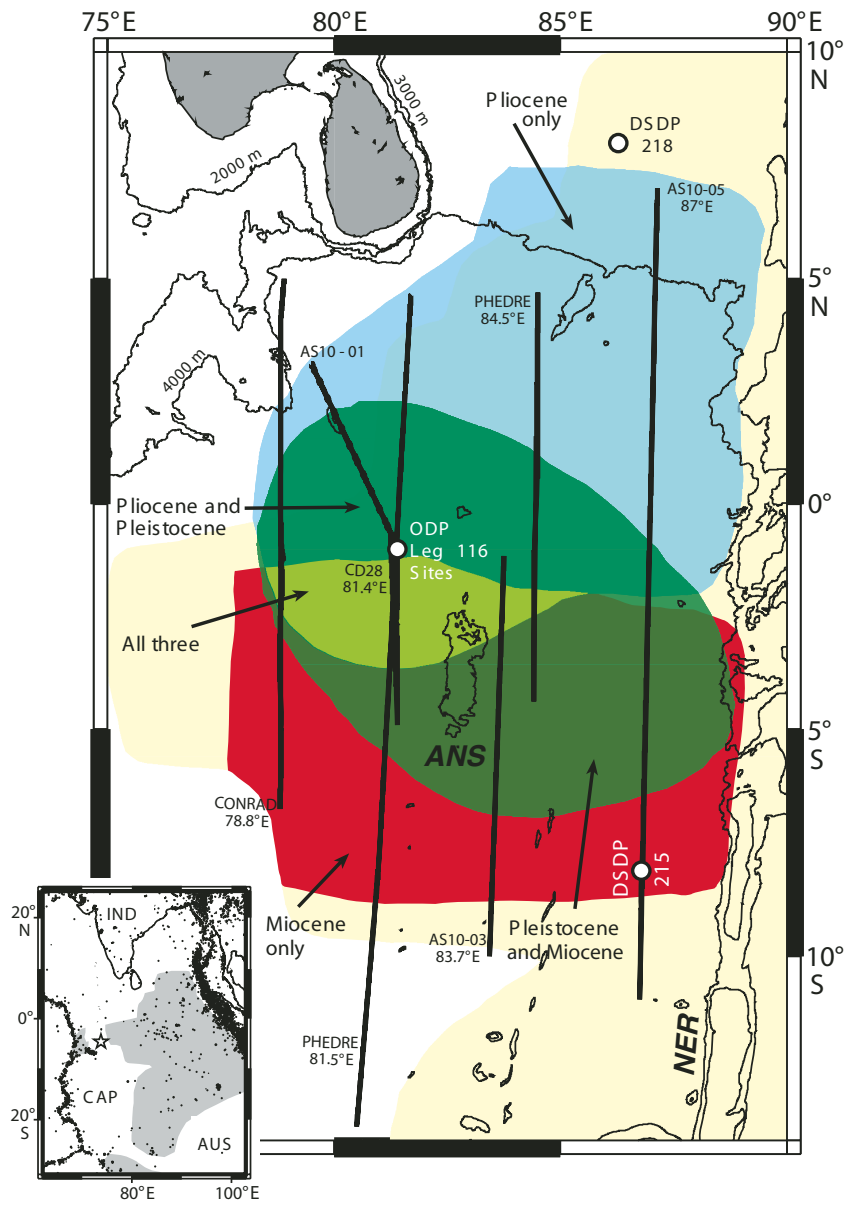

the sedimentary column, we are confident that this limited early extensional motion occurred around or before $20 \mathrm{Ma}$.

\section{STRAIN ESTIMATES IN THE CENTRAL INDIAN OCEAN}

In this study, we integrated all seismic reflection-derived fault displacement data (Krishna et al., 2001; Chamot-Rooke et al., 1993; Jestin, 1994; Van Orman et al., 1995) and applied a systematic common methodology to determine strain (Fig. 1). Previous work has concentrated on deriving total shortening accommodated along different latitudes (Bull and Scrutton, 1992; Chamot-Rooke et al., 1993; Jestin, 1994; Van Orman et al., 1995). A commonly used assumption is that the seismicreflection profiles cover the entire deformation zone. To compare different longitudinal parts of the deformation zone, we prefer to use measurements of total strain, either binned within $100 \mathrm{~km}$ windows with $10 \mathrm{~km}$ rolling bins (Fig. 3) for comparison with long-wavelength basement undulations, or over the deformed length of each profile (Table DR1; Fig. 4).

Determination of strain requires knowledge of fault strike, dip, and the seismic velocity-depth profile. We assume a fault strike of $100^{\circ} \mathrm{E}$ (Bull and Scrutton, 1990a) and a dip of $40^{\circ}$ in base- ment rock (Bull and Scrutton, 1992; ChamotRooke et al., 1993). Given the uncertainties in average velocity of $2600 \mathrm{~m} \mathrm{~s}^{-1}$, representative of the depth interval over which strain calculations were completed, was used (Bull and Scrutton, 1990b). This gives an uncertainty in strain estimates of $\pm 20 \%$. We recognize that the contribution of long-wavelength folding to total shortening is small $(0.1-1.5 \mathrm{~km}$; Bull and Scrutton, 1992; Gordon et al., 1990) compared to reverse faulting $\left(11.2 \pm 2 \mathrm{~km}\right.$ at $78.8^{\circ} \mathrm{E}$, Van Orman et al., 1995 ; to $27 \pm 5 \mathrm{~km}$ at $81.5^{\circ} \mathrm{E}$, ChamotRooke et al., 1993), and, hence, it can be ignored in our calculation of strain. In addition, we added $40 \%$ to our estimates of strain to account for the small faults that are not resolvable on seismicreflection profiles (Walsh et al., 1991). The greatest strain accumulation occurred in general between 8.0 and 7.5 and 5.0-4.0 Ma (Fig. 3). However, as previously reported (Krishna et al., 2001), the relative activity of the faults at different time periods varies spatially. The faults that were active before $8.0 \mathrm{Ma}$ (shown in red in Fig. 3) are widely distributed, and there is a broad correlation with basement highs.

The plot of strain accumulation with time (Fig. 4) demonstrates the early accumulation of relatively small amounts of strain before spatial and vertical variations in velocity, an 
Downloaded from geology.gsapubs.org on October 28, 2014

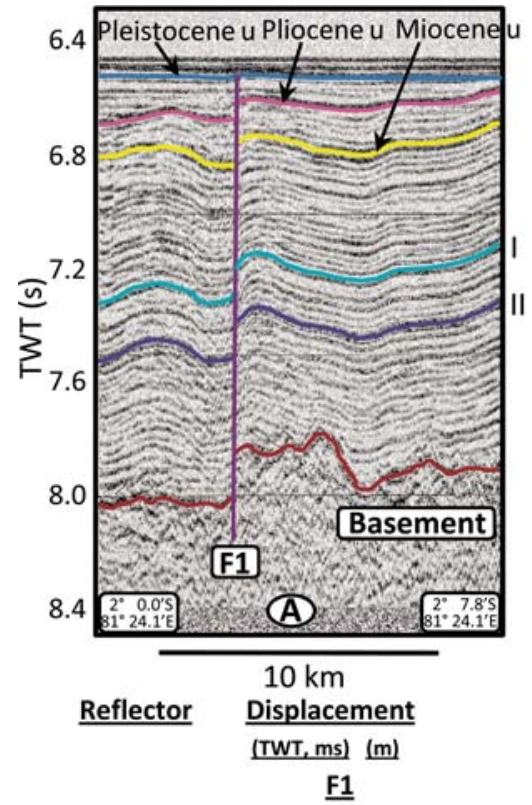

Pleistocene u - $20 \quad 20$

Pliocene u - $80 \quad 80$ Reverse

Miocene u $-120 \quad 120$ - fault

Horizon I $\quad-210 \quad 250$ activity

Horizon II $\quad-210260]$

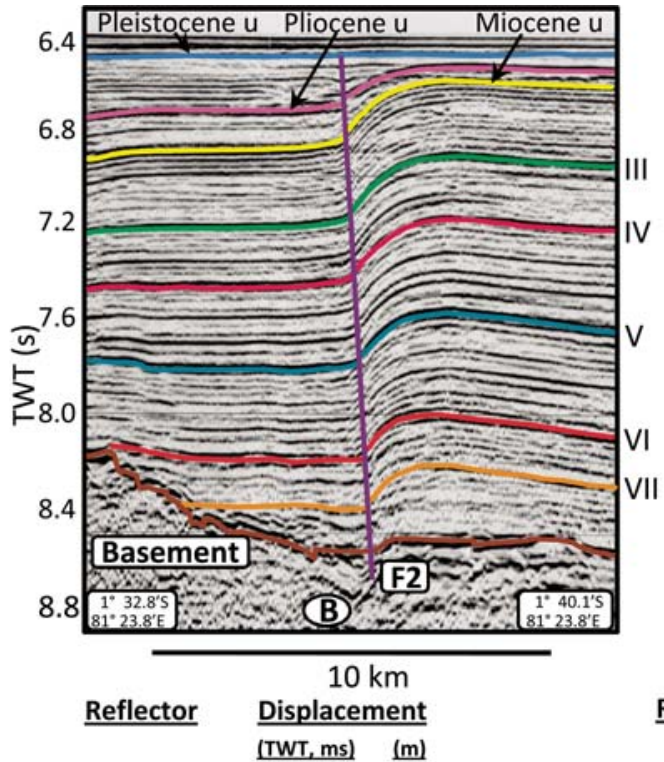

$\underline{\text { F2 }}$

\begin{tabular}{|c|c|c|c|}
\hline & & & \\
\hline Pleistocene & -10 & $10]$ & \\
\hline Pliocene u & -170 & 160 & $\begin{array}{l}\text { Reverse } \\
\text { fault }\end{array}$ \\
\hline Miocene u & -300 & 300 & activity \\
\hline Horizon III & -310 & 340 ] & \\
\hline Horizon IV & -310 & 390 & \\
\hline Horizon V & -290 & 400 & \\
\hline Horizon VI & -250 & 3601 & \\
\hline Horizon VII & -210 & 330 & activity \\
\hline
\end{tabular}

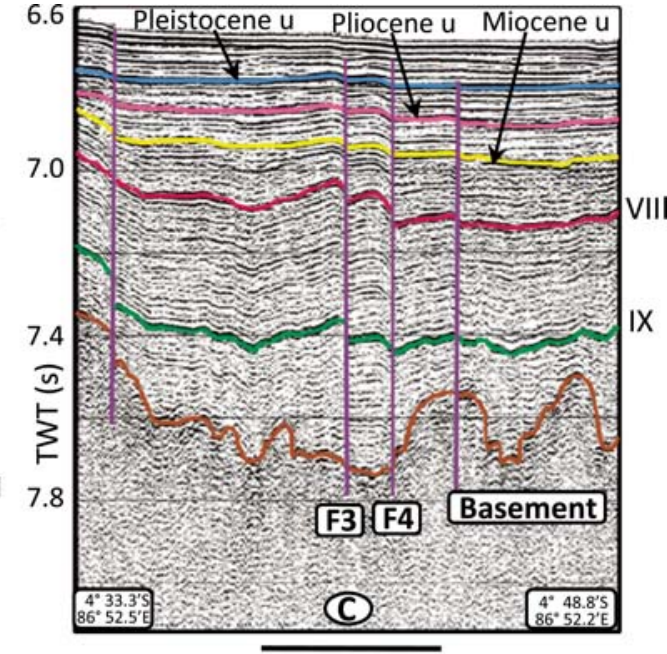

$10 \mathrm{~km}$

Reflector

Displacement

\begin{tabular}{|c|c|c|c|c|c|c|}
\hline & F & & & & & \\
\hline Pleistocene & - 20 & 20 & & 15 & 10 & Reverse \\
\hline Pliocene u & -20 & 20 & Reverse & 25 & 20 & fault \\
\hline Miocene u & -20 & 20 & fault & 25 & 20 & vit \\
\hline Horizon VIII & -45 & 50 & activity & 70 & 70 & \\
\hline Horizon IX & -55 & 60 & & 35 & 40 & $\begin{array}{l}\text { fault } \\
\text { activit }\end{array}$ \\
\hline
\end{tabular}

Figure 2. Three interpreted north-south seismic-reflection profiles illustrating how strain has been accumulated on reverse faults with time over spatially separated regions. In all three sections, Pleistocene (blue), Pliocene (pink), and Miocene (yellow) unconformities are visible. In all sections shown, earlier motion can be demonstrated by greater vertical separation of reflectors on either side of faults at depths greater than Miocene unconformity. Labels on faults indicate those discussed in main text, and those for which activity history is described under each seismic section. For faults F2 and F4, there is clear evidence of early normal motion before reactivation. Depth-dependent velocity law of Bull and Scrutton (1990b) was used to determine displacements in meters. TWT-two-way time.

8.0 $\mathrm{Ma}$, and then the phases of deformation at 8.0-7.5, 5.0-4.0, and 0.8 Ma. There is no simple eastward increase in normalized strain, although there is an increase between $78.8^{\circ} \mathrm{E}$ and $81.5^{\circ} \mathrm{E}$. The most likely explanation for the observed heterogeneity of strain is the role of preexisting structures. The possible role of the Afanasy Nikitin Seamount (ANS) in starting or localizing deformation has been discussed elsewhere (Karner and Weissel, 1990; Krishna et al., 2001; Delescluse and Chamot-Rooke, 2007). Alternatively, the partitioning of deformation within blocks bounded by fracture zones (Bull, 1990; Deplus et al., 1998; Delescluse and ChamotRooke, 2007) may be an explanation. Early normal fault movement is not included in Figure 4 due to its very limited contribution and the lack of age control. This study further reveals that $12 \%$ of the total fault population was active before the formation of the long-wavelength undulations. When strain rate increased at 8.0 $\mathrm{Ma}$, these preexisting structures may have acted to trigger the initiation of folding.
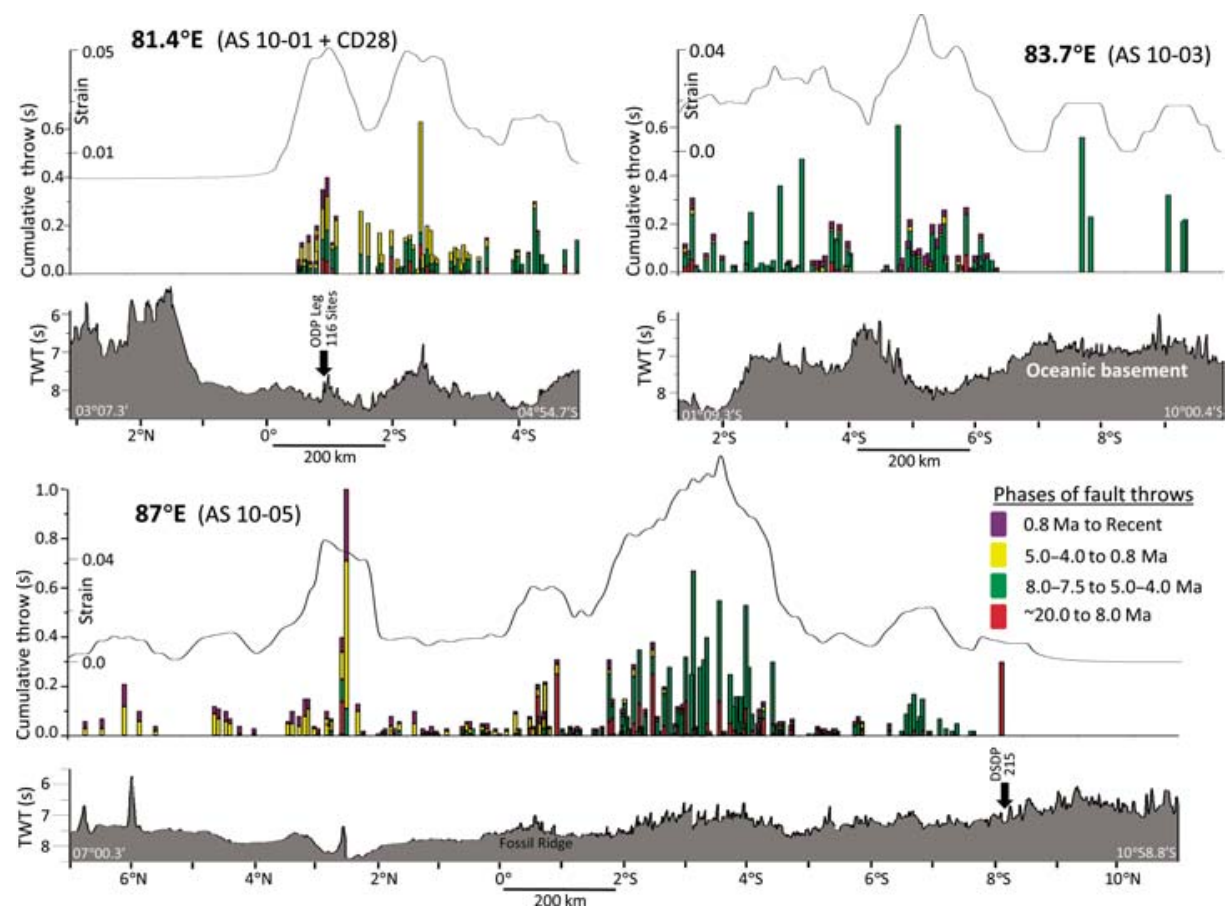

$2^{\circ 9}$

Figure 3. Correlation of basement structure with reverse fault throws measured at four intervals $(20$ to $8.0-7.5 ; 8$ to $5.0-4.0 ; 5.0-4.0$ to 0.8 ; and $0.8-0 \mathrm{Ma}$ ) along seismic profiles at $81.4^{\circ} \mathrm{E}, 83.7^{\circ} \mathrm{E}$, and $87^{\circ} \mathrm{E}$. Strain distribution along each profile is shown above, calculated for $100 \mathrm{~km}$ bins with a rolling window of $10 \mathrm{~km}$. TWT-two-way time; DSDP-Deep Sea Drilling Project; ODP-Ocean Drilling Program. 


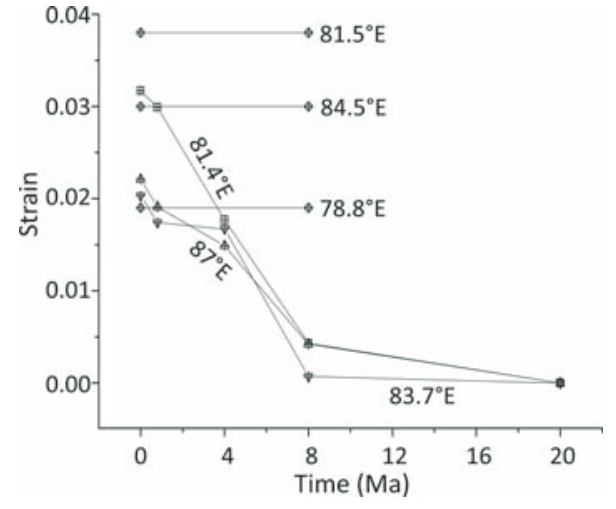

Figure 4. Strain budget calculated from fault throws plotted against age. Strain is normalized by deformation extent on each profile. Fault throw data derived from seismic profiles (Fig. 1) along $81.5^{\circ} \mathrm{E}, 84.5^{\circ} \mathrm{E}$, and $78.8^{\circ} \mathrm{E}$ (Chamot-Rooke et al., 1993; Jestin, 1994; Van Orman et al., 1995), and $81.4^{\circ} \mathrm{E}, 83.7^{\circ} \mathrm{E}$, and $87^{\circ} \mathrm{E}$ (this study) were used for calculation of strain. Lithospheric shortening rate in central Indian Ocean initiated slowly, but increased significantly at $8 \mathrm{Ma}$ and continues, at variable rates, to present.

\section{SUMMARY AND CONCLUSIONS}

Our analysis supports a small amount of early normal movement on isolated faults around or before $20 \mathrm{Ma}$. This was followed by a period of tectonic quiescence, or activity levels below the resolution of our seismic-reflection data. Next, compressional activity within the central Indian Ocean started on isolated, individual fault blocks ca. 15.4-13.9 Ma, and this activity continued slowly until 8.0-7.5 Ma. At 8.0-7.5 Ma, there was a sharp increase in compressional activity, which led to widespread reverse faulting, the formation of earliest long-wavelength folding, and the generation of a regional unconformity. Strain accumulation has been continuous to present, with particular pulses of activity at ca. 5.0-4.0 Ma and 0.8 Ma, which resulted in further long-wavelength folding and displacement on reverse faults. We note that better age control is needed before $8 \mathrm{Ma}$, which requires further deep-sea drilling within the Bengal Fan. Particular attention needs to be placed on the interval between 20 and $10 \mathrm{Ma}$-this interval has been argued to be a period during which the early strengthening of the monsoon occurred (Ramstein et al., 1997), which may be linked to our 15.4-13.9 Ma age range for the onset of compressional deformation in the central Indian Ocean and potentially associated with early Himalayan uplift.

\section{ACKNOWLEDGMENTS}

Krishna thanks the Royal Society for their award of a Royal Society-Council of Scientific and Industrial Research Fellowship to support this research at the National Oceanography Centre, Southampton. We are grateful to Nicolas Chamot-Rooke and James Van Orman for making available their original fault displacement data, and to Eelco Rohling and Tim Henstock for discussions. We thank Sierd Cloetingh and an anonymous reviewer for their constructive comments. This is National Institute of Oceanography (NIO) contribution 4456 .

\section{REFERENCES CITED}

Bull, J.M., 1990, Structural style of intraplate deformation, central Indian Ocean Basin: Evidence for the role of fracture zones: Tectonophysics, v. 184, p. 213-228, doi: 10.1016/0040-1951(90) 90054-C

Bull, J.M., and Scrutton, R.A., 1990a, Fault reactivation in the central Indian Ocean and the rheology of oceanic lithosphere: Nature, v. 344 , p. 855-858, doi: 10.1038/344855a0.

Bull, J.M., and Scrutton, R.A., 1990b, Sediment velocities and deep structure from wideangle reflection data around Leg 116 sites, in Cochran, J.R., Stow, D.A.V., et al., Proceedings of the Ocean Drilling Program, Scientific results, Volume 116: College Station, Texas, Ocean Drilling Program, p. 311-316.

Bull, J.M., and Scrutton, R.A., 1992, Seismic reflection images of intraplate deformation, central Indian Ocean, and their tectonic significance: Journal of the Geological Society of London, v. 149, p. 955-966, doi: 10.1144/gsjgs.149.6.0955.

Chamot-Rooke, N., Jestin, F., de Voogd, B., and Phedre Working Group, 1993, Intraplate shortening in the central Indian Ocean determined from a 2100-km-long north-south deep seismic reflection profile: Geology, v. 21, p. 1043-1046, doi: 10.1130/0091-7613(1993)021 $<$ 1043:ISITCI>2.3.CO;2.

Cochran, J.R., 1990, Himalayan uplift, sea level, and the record of Bengal Fan sedimentation at the ODP Leg 116 sites, in Cochran, J.R., Stow, D.A.V., et al., Proceedings of the Ocean Drilling Program, Scientific results, Volume 116: College Station, Texas, Ocean Drilling Program, p. 397-414.

Curray, J.R., Emmel, F.J., Moore, D.G., and Russel, W.R., 1982, Structure, tectonics, and geological history of the northeastern Indian Ocean, in Nairn, A.E., and Stheli, F.G., eds., The Ocean Basins and Margins: The Indian Ocean, Volume 6: New York, Plenum, p. 399-450.

Curray, J.R., Emmel, F.J., and Moore, D.G., 2002, The Bengal Fan: Morphology, geometry, stratigraphy, history and processes: Marine and Petroleum Geology, v. 19, p. 1191-1223, doi: 10.1016/S0264-8172(03)00035-7.

Delescluse, M., and Chamot-Rooke, N., 2007, Instantaneous deformation and kinematics of the India-Australia plate: Geophysical Journal International, v. 168 , p. 818-842, doi: 10.1111/j.1365-246X.2006.03181.x.

Delescluse, M., Montési, L.G.J., and Chamot-Rooke, N., 2008, Fault reactivation and selective abandonment in the oceanic lithosphere: Geophysical Research Letters, v. 35, p. L16312, doi: 10.1029/2008GL035066.

DeMets, C., Gordon, R.G., and Royer, J.-Y., 2005, Motion between the Indian, Capricorn and Somalian plates since 20 Ma: Implications for the timing and magnitude of distributed lithospheric deformation in the equatorial Indian Ocean: Geophysical Journal International, v. 161, p. 445-468, doi: 10.1111/j.1365-246X. 2005.02598.x

Deplus, C., Diament, M., Heìbert, H., Bertrand, G., Dominguez, S., Dubois, J., Malod, J., Patriat,
P., Pontoise, B., and Sibilla, J.-J, 1998, Direct evidence of active deformation in the eastern Indian oceanic plate: Geology, v. 26, p. 131-134, doi: 10.1130/0091-7613(1998)026 $<0131$ :DEOADI $>2.3$. CO;2.

Gartner, S., 1990, Neogene calcareous nannofossil biostratigraphy, Leg 116 (central Indian Ocean), in Cochran, J.R., Stow, D.A.V., et al., Proceedings of the Ocean Drilling Program, Scientific results, Volume 116: College Station, Texas, Ocean Drilling Program, p. 165-187.

Gordon, R.G., DeMets, C., and Argus, D.F., 1990 Kinematic constraints on distributed lithospheric deformation in the equatorial Indian Ocean from present motion between Australian and Indian plates: Tectonics, v. 9, p. 409-422, doi: 10.1029/TC009i003p00409.

Gordon, R.G., DeMets, C., and Royer, J.-Y., 1998 , Evidence for long-term diffuse deformation of the lithosphere of the equatorial Indian Ocean: Nature, v. 395 , p. $370-374$, doi $10.1038 / 26463$

Henstock, T.J., and Minshull, T.A., 2004, Localised rifting at Chago Bank in the India-Capricorn plate boundary zone: Geology, v. 32, p. 237 240, doi: 10.1130/G19850.1.

Jestin, F., 1994, Cinématique rigide et déformations dans la junction triple Afar et dans le Basin Indien Central [Ph.D. Thesis]: Paris, Universite Pierre et Marie Curie, $217 \mathrm{p}$.

Karner, G.D., and Weissel, J.K., 1990, Compressional deformation of oceanic lithosphere in the central Indian Ocean: Why it is where it is, in Cochran, J.R., Stow, D.A.V., et al., Proceedings of the Ocean Drilling Program, Scientific results, Volume 116: College Station, Texas, Ocean Drilling Program, p. 279-289.

Krishna, K.S., Ramana, M.V., Gopala Rao, D., Murthy, K.S.R., Malleswara Rao, M.M., Subrahmanyam, V., and Sarma, K.V.L.N.S., 1998, Periodic deformation of oceanic crust in the central Indian Ocean: Journal of Geophysical Research, v. 103, p. 17,859-17,875, doi: 10.1029/98JB00078.

Krishna, K.S., Bull, J.M., and Scrutton, R.A., 2001, Evidence for multiphase folding of the central Indian Ocean lithosphere: Geology, v. 29, p. 715-718, doi: 10.1130/0091-7613(2001)029 $<0715$ :EFMFOT $>2.0 . \mathrm{CO} ; 2$

Ramstein, G., Fluteau, F., Besse, J., and Joussaume, S., 1997, Effect of orogeny, plate motion and land-sea distribution on Eurasian climate change over the past 30 million years: Nature, v. 386, p. 788-795, doi: 10.1038/386788a0.

Royer, J.-Y., and Gordon, R.G., 1997, The motion and boundary between the Capricorn and Australian plates: Science, v. 277 , p. 1268-1274 doi: 10.1126/science.277.5330.1268.

Van Orman, J., Cochran, J.R., Weissel, J.K., and Jestin, F., 1995, Distribution of shortening between the Indian and Australian plates in the central Indian Ocean: Earth and Planetary Science Letters, v. 133, p. 35-46, doi: 10.1016/0012-821X(95)00061-G.

Walsh, J., Watterson, J., and Yielding, G., 1991, The importance of small-scale faulting in regional extension: Nature, v. 351, p. 391-393, doi: $10.1038 / 351391 \mathrm{a} 0$

Manuscript received 25 June 2008

Revised manuscript received 24 October 2008

Manuscript accepted 26 October 2008

Printed in USA 